\title{
Identification of antihistone antibodies in subsets of juvenile chronic arthritis
}

\author{
MONIKA ØSTENSEN ${ }^{1}$ KNUT FREDRIKSEN, ${ }^{2}$ ERIK KÅSS, ${ }^{1}$ AND \\ OLE-PETTER REKVIG
}

From the ${ }^{1}$ Oslo Sanitetsforening Rheumatism Hospital, Oslo; and the ${ }^{2}$ Department of Immunology, University of Tromsø, Norway

SUMMARY Antihistone antibodies (AHAs) as measured by an enzyme linked immunosorbent assay (ELISA) were detected in the sera of $58(48 \%)$ of 121 unselected patients with juvenile in chronic arthritis (JCA). AHAs were found in $28(93 \%)$ of 30 patients with JCA with uveitis but in only $30(33 \%)$ of 91 patients with JCA without uveitis. AHA positivity was unrelated to the type of joint involvement, disease activity, and drug regimen. When the AHA positive group was divided into 28 patients with JCA with uveitis and 30 patients with JCA without uveitis a distinct response pattern of AHA was detected in each group. Anti-H3 dominated in the JCA/uveitis group, whereas a more heterogeneous AHA pattern was shown in the group without uveitis. The results indicate that subtyping for AHA reactivity may define patients who are highly susceptible for the development of anterior uveitis.

Key words: anterior uveitis.

Juvenile chronic arthritis (JCA) contains a subset of patients with circulating antinuclear antibodies (ANAs). ${ }^{1}$ The group consists mainly of girls with pauciarticular disease, disease onset before the age of two, and is associated with a greatly increased risk of developing anterior uveitis. ${ }^{2}$ In fact, about $80 \%$ of children with JCA and uveitis are ANA positive. ${ }^{3}$ Thus ANAs can be employed as a marker for predicting the risk for anterior uveitis in patients with JCA. Despite the close relation between ANAs and uveitis associated with JCA the antigenic specifity of this ANA is not known so far.

In the present study of 121 patients with JCA we studied the presence of antihistone antibodies (AHAs), with special emphasis on their pattern in patients with anterior uveitis.

\section{Patients and methods}

One hundred and twenty one patients (90 girls, 31 boys), consecutively admitted to the inpatient or outpatient clinic of the Oslo Sanitetsforening Rheumatism Hospital, were studied. All patients

Accepted for publication 24 June 1988.

Correspondence to Dr Monika Østensen, Oslo Sanitetsforening Rheumatism Hospital, Akersbakken 27, Oslo 1, Norway. had an established diagnosis of JCA according to American Rheumatism Association critera ${ }^{4}$ with disease onset before the age of 16 and a mean disease duration of 6.5 years. The mean age was 11.0 years (range $1-21$ ) in boys and 12.8 years $(2-23)$ in girls. Eleven patients had monarticular JCA, 53 had pauciarticular JCA, and 57 had polyarticular $\mathrm{JCA}$ at the time of investigation. Table 1 gives further clinical details.

All patient records were reviewed by one of us (MØ) and evaluated for the type of disease onset, extra-articular manifestations, results of tests for autoantibodies, and actual drug treatment. Evaluation of disease activity was based on a global assessment, including the active joint count, duration of morning stiffness, functional impairment, and laboratory parameters such as erythrocyte sedimentation rate (Westergren), haemoglobin, and platelet counts. Disease activity was graded as none $(0)$, moderate (1), or severe (2). No separate grading of the activity of eye involvement was made in patients with anterior uveitis.

A serum sample was taken from each patient and analysed for the presence of autoantibodies immediately. An additional serum sample was kept frozen at $-20^{\circ} \mathrm{C}$ until used. 
Table 1 Clinical data on 121 patients with juvenile chronic arthritis at entry to the study

\begin{tabular}{|c|c|c|c|c|c|c|c|c|c|c|c|}
\hline \multirow[t]{2}{*}{ Sex } & \multirow[t]{2}{*}{ Number } & \multirow{2}{*}{$\begin{array}{l}R F^{*} \\
\text { positive }\end{array}$} & \multirow{2}{*}{$\begin{array}{l}\text { ANA* } \\
\text { positive }\end{array}$} & \multirow{2}{*}{$\begin{array}{l}\text { History } \\
\text { of uveitis }\end{array}$} & \multicolumn{4}{|c|}{ Type of onset } & \multicolumn{3}{|c|}{ Courset } \\
\hline & & & & & 1 & 2 & 3 & 4 & 1 & 2 & 3 \\
\hline $\mathbf{F}$ & 90 & 4 & 45 & 21 & 19 & 33 & 32 & 6 & 5 & 40 & 45 \\
\hline $\mathbf{M}$ & 31 & 2 & 16 & 9 & 7 & 15 & 5 & 4 & 6 & 13 & 12 \\
\hline Total & 121 & 6 & 61 & 30 & 26 & 48 & 37 & 10 & 11 & 53 & 57 \\
\hline
\end{tabular}

${ }^{*} \mathrm{RF}=$ rheumatoid factor; ANA = antinuclear antibody.

$\dagger 1$ =monarticular; $2=$ pauciarticular; $3=$ polyarticular; $4=$ systemic, febrile.

ANTINUCLEAR ANTIBODIES

The presence of ANAs in serum was tested by indirect immunofluorescence using $\mathrm{HEp}_{2}$ cells as substrate and fluorescein isothiocyanate conjugated rabbit antibuman $\mathrm{Fc}$ antibodies.

ANTIHISTONE ANTIBODIES AND ANTI-dSDNA ANTIBODIES

Serum samples with a titre $>1 / 16$ in the fluorescence ANA test were examined for antibody activities against individual histone classes $(\mathrm{H} 1, \mathrm{H} 2 \mathrm{~A}, \mathrm{H} 2 \mathrm{~B}$, $\mathrm{H} 3$, and $\mathrm{H} 4$ ) and against double stranded DNA by an indirect solid phase enzyme linked immunosorbent assay (ELISA) (Neosystem, Laboratoires SA, Strasbourg, France) as described by Rekvig et al. ${ }^{5}$

\section{Results}

CLINICAL PARAMETERS

Of the 121 patients, $28(23 \%)$ received no drug treatment, $36(30 \%)$ were treated with non-steroidal anti-inflammatory drugs alone, and $57(47 \%)$ were treated with disease modifying drugs including cytostatic drugs together with non-steroidal antiinflammatory drugs or corticosteroids. None of the patients received D-penicillamine or sulphasalazine, which have been shown to induce antihistone antibodies. ${ }^{6}$ Twenty six $(21 \%)$ of the patients had inactive disease, $62(51 \%)$ had moderate, and 33 $(27 \%)$ severe disease activity. Severe disease activity was almost exclusively found in the polyarticular group.

Eighty eight $(73 \%)$ patients had no organ involvement, one had had pleuropericarditis, three had amyloidosis, one had mononeuritis, and $30(25 \%)$ had previous or ongoing anterior uveitis with severe impairment of vision in six cases.

\section{A UTOANTIBODIES}

ANAs had been or were still (10 patients) present in $61(50 \%)$ of all patients, whereas only $10(8 \%)$ were positive for rheumatoid factor. None of the ANA positive patients had anti-native DNA antibodies.
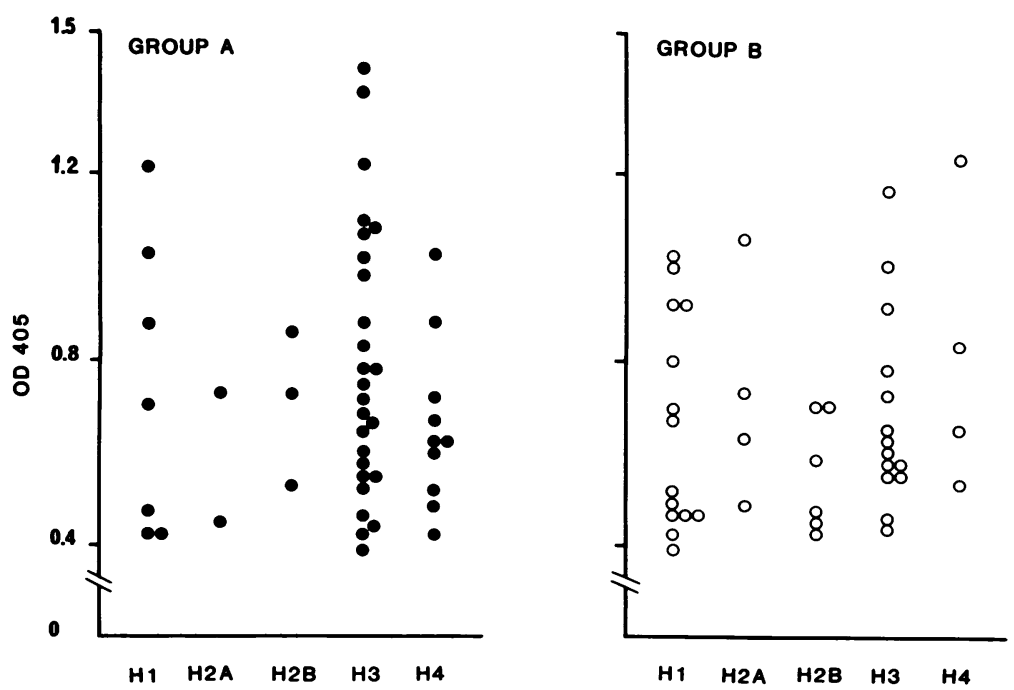
Fig. 1 Serum concentrations of antihistone antibodies in 28 patients with juvenile chronic arthritis (JCA) with uveitis (group $A)$ and 30 patients with $J C A$ without uveitis (group B). Serum antibodies to five histone classes- $\mathrm{H} 1, \mathrm{H} 2 \mathrm{~A}, \mathrm{H} 2 \mathrm{~B}, \mathrm{H} 3$, and $\mathrm{H} 4$ were measured by an enzyme linked immunosorbent assay (ELISA). = group $A ; \bigcirc=$ group B.


ANTIHISTONE ANTIBODIES

AHAs were detected in altogether 58 patients, 45 of whom had also been positive for ANAs at some point of their disease. The AHA positive group was divided into 28 patients with uveitis (group A) and 30 patients without uveitis (group B). The two groups were comparable with regard to disease activity and drug regimens. An equal distribution of ANA titres recorded during the disease was found, with a median ANA titre of 64 (range 16-1024) in 27 patients in group $A$ and 18 in group $B$.

Figure 1 and Table 2 show the pattern of AHAs in the two groups of patients with JCA. When groups $A$ and $B$ were compared it was found that $9 v 22$ patients had AHAs which showed reactivity to only one histone, $16 \mathrm{v} 6$ had AHAs directed against two histones, and $3 v 2$ had AHAs directed against three or more histone classes. The highest reactivity was found to be directed against $\mathrm{H} 3$ in group $\mathrm{A}$ (Fig. 1). In group $B$ the reactivity to anti-H1 and anti-H3 was equally frequent and of the same magnitude (Fig. 1, Table 2).

When the 30 patients with JCA and uveitis were compared with the 91 patients with JCA without uveitis (Table 3 ) the uveitis group differed from the non-uveitis group by an excess of ANA and AHA positivity, a predominantly pauciarticular type of

Table 2 The antihistone response in 28 patients with juvenile chronic arthritis (JCA) with uveitis (group A) and 30 patients with JCA without uveitis (group B)

\begin{tabular}{llr}
\hline $\begin{array}{l}\text { Antihistone } \\
\text { antibody }\end{array}$ & \multicolumn{2}{l}{ No (\%) positive } \\
\cline { 2 - 3 } & Group $A$ & Group B \\
\hline Anti-H1 & $7(25)$ & $14(47)$ \\
Anti-H2A & $2(7)$ & $4(13)$ \\
Anti-H2B & $3(11)$ & $6(20)$ \\
Anti-H3 & $26(93)$ & $14(47)$ \\
Anti-H4 & $10(36)$ & $4(13)$ \\
\hline
\end{tabular}

onset, a lower age at disease onset, and longer disease duration. The differences in ANA and AHA positivity were significant $(\mathrm{p}<0.0001)$ by applying the $\chi^{2}$ test with Yates's correction.

\section{Discussion}

We used an ELISA to detect AHAs in $58(48 \%)$ of an unselected group of 121 patients with JCA. Forty"s five of the AHA positive patients had also been. positive for ANA at some stage of their disease. More than $90 \%$ of the AHA/ANA positivity waso detected in the JCA subgroup with uveitis, contrasting with only about $35 \%$ positivity in the patients. with JCA without uveitis.

Few reports on the prevalence of AHAs in $\mathrm{JCA}^{\text {? }}$ exist. ${ }^{7}$ Preliminary observations with immunoblot $-\overrightarrow{\vec{A}}$ ting have suggested the presence of anti-H1 in 180 $(56 \%)$ of 32 sera of pauciarticular JCA ${ }^{8}$ Weill and Menkes found a higher percentage of AHA and T ANA positivity in their study of 47 patients witho JCA with mono/pauciarticular disease. ${ }^{9}$ They did not comment on the presence or absence of uveitis, however, nor did they report the antihistone re- $\overrightarrow{0}$ sponse pattern. In another study $6(15 \%)$ of $\$ 10$ patients with JCA displayed antihistone reactivi mainly against $\mathrm{H} 2 \mathrm{~B} .^{10}$ In our study the prevailingo antibody in the entire AHA positive group was antiH3.

A high proportion of ANA positive patients with JCA, yet not all, develop anterior uveitis. ${ }^{7} \mathrm{We}^{\Omega}$ therefore analysed an AHA positive subgroup of $28 \overline{\overline{0}}$ patients with JCA with a history of anterior uveitis ${ }^{\exists}$ (group A) and compared them with 30 AHA positive patients with JCA without uveitis (group B). Despite minor differences in the presenting clinical picture, including actual disease activity, ${ }^{\circ}$ type of joint affection, and drug treatment, a distinct 3 . autoimmune response to histones was found in thei two groups. Analysis of the pattern of AHAs showed a predominance of anti-H3, which alone oro

Table 3 Clinical data on 30 patients with juvenile chronic arthritis (JCA) and uveitis and 91 patients with JCA without uveitis

\begin{tabular}{|c|c|c|c|c|c|c|c|c|c|c|c|c|c|}
\hline \multirow[t]{2}{*}{ Group } & \multirow{2}{*}{$\begin{array}{l}\text { Femalel } \\
\text { male }\end{array}$} & \multicolumn{3}{|c|}{ Positivity (\%) of: } & \multirow{2}{*}{$\begin{array}{l}\text { Mean } \\
\text { disease } \\
\text { duration } \\
\text { (range) }\end{array}$} & \multirow{2}{*}{$\begin{array}{l}\text { Mean } \\
\text { age at } \\
\text { onset } \\
\text { (range) }\end{array}$} & \multicolumn{4}{|c|}{ Type of onset $\dagger$} & \multicolumn{3}{|c|}{ Courset } \\
\hline & & $R F^{*}$ & $A N A^{*}$ & $A H A^{*}$ & & & 1 & 2 & 3 & 4 & 1 & 2 & 3 \\
\hline With uveitis & $21 / 9$ & 0 & 97 & 98 & $\begin{array}{l}8 \cdot 7 \\
(2-14)\end{array}$ & $\begin{array}{l}3 \\
(1-9)\end{array}$ & 5 & 22 & 2 & 1 & 0 & 17 & 13 \\
\hline Without uveitis & $69 / 22$ & 8 & 35 & 33 & $\begin{array}{l}6 \cdot 7 \\
(2-14)\end{array}$ & $\begin{array}{l}7 \\
(1-15)\end{array}$ & 18 & 27 & 36 & 10 & 10 & 34 & 47 \\
\hline
\end{tabular}


combined with other AHAs was detected in 26 $(93 \%)$ of the 28 patients with JCA with uveitis. By contrast, the 30 patients with JCA positive for AHAs but without uveitis showed a more heterogeneous pattern of AHA. Most of group A showed reactivity to more than one histone class, whereas patients in group B reacted mostly to one histone only. In the present study the presence and titre of AHAs were unrelated to the activity of joint inflammation, ANA positivity or titre, and drug treatment. Extended studies are warranted to investigate the temporal relation between the AHA response and the onset of uveitis and to discover whether the AHA pattern shown by us is specific for uveitis without JCA.

Disease related patterns of antihistone response have been shown for rheumatoid arthritis, idiopathic systemic lupus erythematosus, and drug induced systemic lupus erythematosus ${ }^{6}$ but have not been demonstrated for JCA. Despite the surprisingly high proportion of anti-H3 reactivity in the uveitis group a causative role of AHAs, and especially those against $\mathrm{H} 3$ in uveitis, is unlikely for the following reasons: $13 \%$ of the patients with $\mathrm{JCA} /$ uveitis did not display anti-H3 reactivity and $35 \%$ of all anti/H3 positive patients with JCA did not have uveitis.

To conclude, the present data show a high prevalence of circulating AHAs in JCA, mainly directed against $\mathrm{H} 3$ and $\mathrm{H} 1$. Our results suggest a distinction between the ANA specificities in ANA positive JCA associated with uveitis versus JCA without uveitis. As the mere presence of ANAs is not predictive for the development of anterior uveitis in JCA, subtyping the patients for AHA reactivity may define an ANA positive subgroup which is highly susceptible for uveitis.

We are grateful to Dr Sylviane Muller, Institute of Molecular and Cellular Biology, Strasbourg, France, for valuable support and for providing the Nucleoscreen test.

\section{References}

1 Petty R E, Cassidy J T, Sullivan D B. Clinical correlates of antinuclear antibodies in juvenile rheumatoid arthritis. $J$ Pediatr 1973; 83: 386-9.

2 Schaller J G, Johnson G D, Holborow E J, Ansell B M, Smiley W K. The association of antinuclear antibodies with the chronic iridocyclitis of juvenile rheumatoid arthritis (Still's disease). Arthritis Rheum 1974; 17: 409-16.

3 Rosenberg A M. Uveitis associated with juvenile rheumatoid arthritis. Semin Arthritis Rheum 1987; 16: 158-73.

4 Brewer E J, Bass J, Baum J, et al. Current proposed revision of JRA criteria. Arthritis Rheum 1977; 20: 195-9.

5 Rekvig O P, Muller S, Briand J P, Skogen B, van Regenmortel M H V. Human antinuclear autoantibodies crossreacting with the plasma membrane and the $\mathrm{N}$-terminal region of histone H2B. Immunological Investigations 1987; 16: 535-47.

6 Hobbs R N, Clayton A-L, Bernstein R M. Antibodies to the five histones and poly(adenosine diphosphate-ribose) in drug induced lupus: implications for pathogenesis. Ann Rheum Dis 1987; 46: 408-16.

7 Leak A M. Autoantibody profile in juvenile chronic arthritis. Ann Rheum Dis 1988; 47: 178-82.

8 Malleson P N, Fung M, Petty R E. Antigenic heterogeneity of antinuclear antibodies in juvenile rheumatoid arthritis determined by immunoblotting [Abstract]. Arthritis Rheum 1987; 30: S126.

9 Weill B J, Menkes C J. Antinuclear, antideoxyribonucleoprotein and anti-histone antibodies in juvenile chronic arthritis and transient hip synovitis. Br J Rheumatol 1987; 26 (suppl): 75.

10 Brunet C, Craft J, Nakamura M, Pachman T, Athreya B, Hardin J. Identification of nuclear antigens bound by sera from patients with juvenile rheumatoid arthritis. Arthritis Rheum 1986; 29 (suppl): S67. 